\title{
Uma incursão ao pathos: o método aristotélico de descrição das paixões e a relação hierárquica delas emanada
}

\section{Maria Flávia Figueiredo Valmir Ferreira dos Santos Júnior}

$\mathrm{O}$ intuito aristotélico de sistematizar uma faceta da comunicação humana culminou em um profundo estudo sobre como a interlocução persuasiva se organiza. Dessa forma, Aristóteles, com sua obra Retórica, apresenta seu método descritivo das particularidades discursivas em âmbito retórico. Isso fica evidente quando descreve que o intuito da arte retórica é observar os

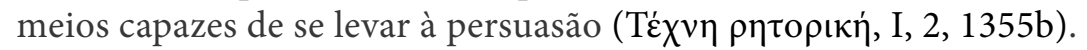

Para que um discurso seja capaz de desencadear processos persuasivos, é necessário que todas as engrenagens do sistema retórico estejam alinhadas e funcionem em pleno vigor. Na obra aristotélica, são três as engrenagens fundamentais que, ao interagirem perfeitamente em conjunto, levam à persuasão do auditório: (i) o caráter do orador (que deve demonstrar ser benevolente, sincero e detentor de conhecimento a respeito daquilo de que trata); (ii) a estrutura do discurso (que deve ser clara, organizada e crível em seus constituintes argumentativos); e (iii) o trabalho com as emoções (que devem ser despertadas naqueles que julgam a validade do que o orador apresenta, haja vista que elas dispõem o homem em determinados estados mentais que influenciam na forma como ele julga uma questão).

O foco da presente discussão reside no item (iii), uma vez que ele remete ao pathos, ou seja, a prova artística, como pontua Aristóteles, ${ }^{1}$ que lida com as emoções no âmbito persuasivo. Especificamente, este capítulo apresentará uma categorização da descrição aristotélica sobre as 14 paixões em sua obra Retórica, com base nas três premissas fundamentais que o mestre estagirita apresenta,

1 Aristóteles descreve provas artísticas como as provas que dependem da criação do orador em um discurso persuasivo, em contraposição com as provas inartísticas, que não dependem da criação do orador, em outras palavras, que já estão disponíveis no mundo, como leis, testemunhos e confissões 
quais sejam: em que estado de espírito se encontra quem sente determinada paixão (relaciona-se à disposição para determinada emoção causada no auditório pelo discurso em questão); em relação a quem ou a que se sente uma dada paixão; e em que circunstância tal paixão é evocada. Esse, portanto, é o método estabelecido por Aristóteles para descrever as 14 paixões de sua Retórica (de

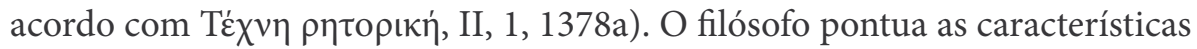
das afecções em uma perspectiva comparativa, com base nos três aspectos mencionados. Ademais, expõe que tal caracterização serve ao orador como um guia para o despertar das paixões.

Além de apresentar a categorização mencionada, este capítulo também trará uma reflexão acerca da relação que o sujeito que sente determinada paixão constrói com aquele, ou aquilo, que desperta nele tal paixão. Essa relação, como será exposto adiante, detém caráter hierárquico, uma vez que sempre apresenta aquele que sente uma paixão de forma inferior, igual ou superior, em relação àquele, ou àquilo, que desperta tal emoção.

Essa reflexão é profícua em sentido retórico ao passo que o processo persuasivo depende diretamente da forma com que um auditório se sente em relação à tese apresentada. Assim, é importante que o orador compreenda as relações hierárquicas emanadas das paixões despertadas para que possa trabalhar as posições a serem ocupadas pelo auditório (inferior, igual ou superior) de acordo com seu intuito persuasivo.

Sendo assim, este capítulo abarca uma discussão acerca do método aristotélico na descrição das paixões e também a proposição de uma quarta premissa a tal método, a relação de hierarquia criada pelas paixões. Espera-se que tal reflexão auxilie no estudo do conceito de pathos pelo viés aristotélico por propor uma descrição objetiva das paixões, focada nas três premissas mencionadas e por introduzir uma nova perspectiva para a temática. Com o intuito de organizar a leitura deste texto, em primeiro lugar será introduzida a categorização do texto aristotélico e, em segundo, a proposição da premissa hierárquica.

\section{As 14 paixões aristotélicas e as três premissas que as descrevem}

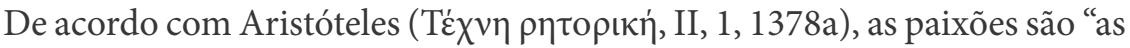
causas que fazem alterar os seres humanos e introduzem mudanças nos seus juízos, na medida em que elas comportam dor e prazer". Isso se dá de forma transitória e não permanente, pois, do contrário, tratariam de vícios e virtudes. Por meio dessa proposição, é possível destacar três pontos que caracterizam o 
Uma incursão ao pathos: o método aristotélico de descrição das paixões e a relação hierárquica delas emanada

despertar de uma emoção: (1) a alteração no espírito; (2) a mudança a respeito de um juízo; e (3) a evocação de dor ou prazer. Esses três pontos não são apresentados por Aristóteles nessa ordem fortuitamente, mas sim da forma com que ocorrem no processo de evocação de uma paixão na psique humana. Dessa maneira, Aristóteles ressalta que as paixões alteram o estado psicológico daqueles que as sentem e isso, por consequência, reformula uma concepção a respeito de determinada questão. Por fim, tal reformulação auxilia no processo de evocação de fantasias que atuam diretamente nas respostas, sinalizadas pela evocação de dor ou prazer.

Logicamente, tal processo é útil para a Retórica, uma vez que pode direcionar um determinado auditório de acordo com o que o orador deseja, em sentido persuasivo. Com base nisso, as 14 paixões apresentadas por Aristóteles, no Livro II de sua Retórica, apresentam-se como um leque de possibilidades retóricas para aquele que se encontra na necessidade de proferir um discurso, logo, de apresentar uma tese à adesão de um auditório.

Nos itens subsequentes, serão apresentadas as paixões em questão, detalhadas nas premissas que as descrevem. São elas: ira (cólera); calma; amor (amizade); ódio (inimizade); medo (temor); confiança (esperança); vergonha; desvergonha (impudência); favor (amabilidade); compaixão (piedade); indignação; inveja; emulação; e desprezo.

\section{Ira (cólera)}

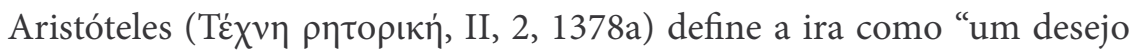
acompanhado de dor que nos incita a exercer vingança explícita devido a algum desprezo manifestado contra nós, ou contra pessoas da nossa convivência, sem haver razão para isso". Além disso, afirma que "toda ira é acompanhada de certo prazer, resultante da esperança que se tem de uma futura vingança". Por fim, pontua, em relação à oposição de outrem no caminho do colérico, que "cada pessoa abre caminho à sua própria ira, vítima da paixão que possui”.

Em qual disposição se encontra quem sente: quem se encoleriza habita o estado emocional de vingança, uma vez que a representação mental de vingarse daquele que nos causa mal, ou aos nossos queridos, traz prazer. O colérico encontra-se nesse estado porque se sente desdenhado, menosprezado, difamado, desvalorizado e ultrajado. Em adição a isso, quando estão tristes, as pessoas se encolerizam, pois quem sente amargura, proveniente da tristeza, é porque deseja algo, tem carência de algo. Em consonância com o ponto anterior, alguém se torna colérico quando outros se opõem a sua ação, decisão ou pensamento, ou seja, quando não pode alcançar o que deseja pela oposição de outrem. Dessa 
forma, aqueles que estão dispostos pelo discurso a tornarem-se coléricos são os menosprezados, pois, também se encontram tristes e, ao mesmo tempo, esperançosos em relação ao alcance da vingança.

Contra quem sente: quem sente ira, sente tal afecção contra um determinado indivíduo, não contra o homem em geral. Sente-a contra o desdenhoso, o ultrajante e o menosprezador. No geral, sentimos cólera contra o indivíduo em particular que nos menospreza.

Em qual circunstância sente: em função de algum agravo que lhe fizeram ou pretendiam fazer, a ele ou a algum dos seus. Dessa forma, de acordo com o estagirita, a circunstância que fundamenta a paixão da cólera é o menosprezo, a diminuição, vista como injusta pelo colérico, de seu valor ou do valor de alguém que lhe é caro.

Com base nesse levantamento da descrição aristotélica, o seguinte quadro é proposto:

Quadro 1 - Premissas da ira (cólera)

\begin{tabular}{|l|l|l|}
\hline \multicolumn{2}{|c|}{ Cólera } \\
\hline $\begin{array}{l}\text { Em qual disposição se encontra } \\
\text { quem sente: }\end{array}$ & Contra quem sente: & $\begin{array}{l}\text { Em qual } \\
\text { circunstância: }\end{array}$ \\
\hline Menosprezado, vingativo. & O homem em particular desdenhoso. & $\begin{array}{l}\text { Quando } \\
\text { desvalorizado, } \\
\text { injustiçado, } \\
\text { diminuído. }\end{array}$ \\
\hline
\end{tabular}

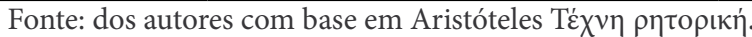

\section{A calma}

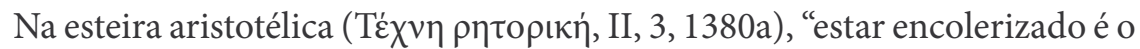
contrário de estar calmo, e a cólera é o oposto da calma”. Sendo assim, a calma é o contrário da ira (cólera). O autor continua sua descrição ao afirmar que "a calma pode ser definida como um apaziguamento e uma pacificação da cólera"

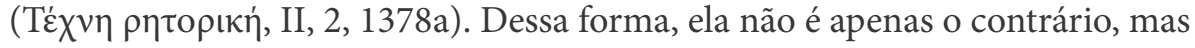
também a 'solução' para a ira, o antídoto da cólera, uma vez que remedia tal paixão.

Em qual disposição se encontra quem sente: quem é acometido pela calma está disposto nas circunstâncias da felicidade, da esperança, da bem aventurança e, em geral, todas aquelas disposições contrárias que promovem a cólera, como a paciência e a ausência de dor. Pode-se sintetizar, portanto, os estados de espírito que promovem a calma como: a esperança; a felicidade; a ausência de dor; a vingança (e a justiça); e a paciência. 
Uma incursão ao pathos: o método aristotélico de descrição das paixões e a relação hierárquica delas emanada

Em relação a quem sente: àqueles que não menosprezam outrem ou, quando o fazem, fazem-no involuntariamente. As pessoas também se sentem calmas em relação àqueles que se arrependem do mal que cometeram e que mantém a seriedade ao falar, pois, por consequência, se agem de tal modo demonstram não desdenhar. Além disso, em geral, com os suplicantes e generosos na retribuição de um favor se é calmo. Por fim, se é calmo quando acredita sofrer uma punição merecida. Ao retomar as discrições anteriores, é possível apontar que se sente calma em relação àqueles que são sérios, sensatos e não menosprezam.

Em qual circunstância sente: quando acredita não estar passando por um mal imerecido, quando recebe o que lhe é de direito, ou de merecimento, até mesmo quando o que merece é danoso.

Quadro 2 - Premissas da calma

\begin{tabular}{|l|l|l|}
\hline \multicolumn{2}{|c|}{ Calma } \\
\hline $\begin{array}{l}\text { Em qual disposição se } \\
\text { encontra quem sente: }\end{array}$ & Contra quem sente: & Em qual circunstância: \\
\hline $\begin{array}{l}\text { Esperançoso, paciente, } \\
\text { próspero. }\end{array}$ & $\begin{array}{l}\text { A pessoa séria e que não } \\
\text { menospreza. }\end{array}$ & $\begin{array}{l}\text { Quando se acredita } \\
\text { não estar sofrendo por } \\
\text { nenhum mal imerecido. }\end{array}$ \\
\hline
\end{tabular}

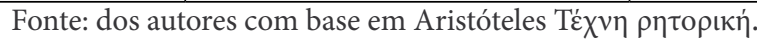

\section{A amizade (o amor)}

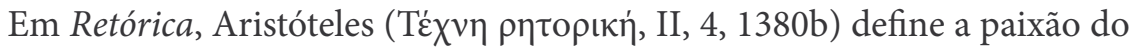
amor, ou amizade, como "querer para alguém aquilo que pensamos ser uma coisa boa, por causa desse alguém e não por causa de nós".

Em qual disposição se encontra quem sente: as pessoas amam quando se encontram em disposição emocional harmônica, sincrônica, de irmandade, de respeito e de reciprocidade com outrem. Ademais, ama-se quando prestam favor de forma despretensiosa.

Em relação a quem sente: àquele que ama reciprocamente. Os que se encontram mutuamente na relação de querer o bem do outro. Sente-se amor por aqueles que amam e odeiam o mesmo que nós. Sente-se amor por aqueles que consideram como bens ou males as mesmas coisas que nós. De forma geral, amamos os que demonstram possuir afinidades conosco. Ademais, se ama aqueles que são bondosos (conosco ou com os que nos são caros) ou que nos valorizam.

Em qual circunstância sente: quando pensa lidar com outrem que é recíproco em querer seu bem, quando lida com alguém que o respeita da mesma maneira que respeita esse alguém. Ademais, aquele que sente amor, se sente de 
tal forma quando se encontra em situação de companheirismo, de familiaridade, de parentesco e de qualquer laço sentimental profundo.

\begin{tabular}{|l|l|l|}
\hline \multicolumn{2}{|c|}{ Quadro 3 - Premissas do amor } \\
\hline $\begin{array}{l}|c| \\
\text { Em qual disposição se } \\
\text { encontra quem sente: }\end{array}$ & Contra quem sente: & Em qual circunstância: \\
\hline $\begin{array}{l}\text { Paridade, harmonia, } \\
\text { reciprocidade. }\end{array}$ & $\begin{array}{l}\text { O homem que tem como } \\
\text { bem ou mal o mesmo que } \\
\text { nós e nos faz o bem sem } \\
\text { pretensão de retribuição. }\end{array}$ & $\begin{array}{l}\text { Quando acredita estar em } \\
\text { relação de companheirismo, } \\
\text { afinidade, familiaridade ou } \\
\text { qualquer outro laço que } \\
\text { propicie o zelo. }\end{array}$ \\
\hline
\end{tabular}

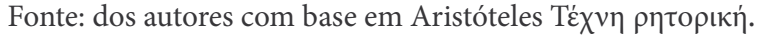

\section{A inimizade (o ódio)}

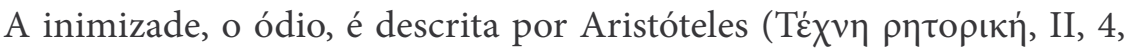
1382a) como o contrário do amor. Em comparação com a cólera, o estagirita aponta que se sente ódio pela classe, não pelo indivíduo. Enquanto na cólera há uma razão pessoal para o seu despertar, no ódio, tal motivação particular não precisa existir, uma vez que ele é mais abrangente do que a cólera, é sentido, portanto, em relação ao homem de forma geral. Odeiam-se as classes, os tipos, os arquétipos, não o particular, o específico, o único. Sente-se ódio dos ladrões, em geral, pois se o sentimento de pesar é voltado para o homem que praticou dado ato criminoso, o que se sente é cólera. Dessa forma, odeiam-se os políticos corruptos, mas se o desgosto é voltado apenas para um indivíduo, tem-se ira dele em específico, não ódio. Além disso, é possível também odiar coisas, ao passo que não é possível ter ira (sentir cólera) de coisas, portanto odeiam-se aviões, mas não é possível encolerizar-se contra eles. Nas palavras do autor: "A cólera é o desejo de causar desgosto, mas o ódio, o de fazer mal, visto que o colérico quer notar o desgosto causado, enquanto ao que odeia nada importa" (Té $\chi \nu \eta$

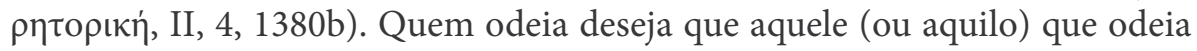
desapareça, ao passo que quem sente ira deseja que seu desgosto seja provado por aquele que o causa.

Em qual disposição se encontra quem sente: o homem sente ódio quando se encontra em situação de disparidade, adversidade, quando algum tipo apresenta uma visão ou opinião que contradiz seus valores e crenças e, por consequência, tal contradição lhe faz mal.

Em relação a quem sente: sente-se inimizade pela classe, pelo estereótipo, pelo arquétipo e não pelo indivíduo, pelo particular. Dessa maneira, odeiam-se 
Uma incursão ao pathos: o método aristotélico de descrição das paixões e a relação hierárquica delas emanada

os insensatos, os viciados, os corruptos, os bandidos e todo tipo que se apresenta em desordem com a visão de bem do sujeito que sente tal paixão. Ademais, odeiam-se as coisas que nos causam adversidade e, por consequência, tal adversidade nos causa mal-estar.

Em qual circunstância sente: assim como na cólera, sente-se inimizade quando o homem se encontra ultrajado, caluniado, menosprezado. A diferença é que tal estado provém de uma concepção acerca de uma classe e não de um indivíduo.

Quadro 4 - Premissas do ódio

\begin{tabular}{|l|l|l|}
\hline \multicolumn{3}{|c|}{ Ódio } \\
\hline $\begin{array}{l}\text { Em qual disposição se } \\
\text { encontra quem sente: }\end{array}$ & Contra quem sente: & Em qual circunstância: \\
\hline $\begin{array}{l}\text { Disparidade, adversidade, } \\
\text { desencontro. }\end{array}$ & $\begin{array}{l}\text { O tipo de homem, ou classe de } \\
\text { homem, que traz algum mal em } \\
\text { consequência de uma visão ou } \\
\text { ponto de vista adverso daquele } \\
\text { que é acometido pelo ódio. } \\
\text { Da mesma forma, odiamos } \\
\text { as coisas que acreditamos nos } \\
\text { fazer mal. }\end{array}$ & $\begin{array}{l}\text { Quando acredita estar em } \\
\text { relação de disparidade } \\
\text { e se sente caluniado, } \\
\text { desprezado, ultrajado. }\end{array}$ \\
\hline
\end{tabular}

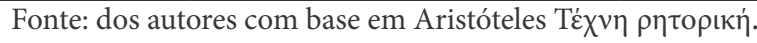

\section{O temor (medo)}

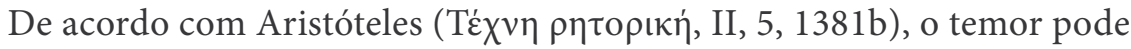
ser definido como "desgosto ou preocupação resultantes da suposição de um mal iminente, ou danoso ou penoso". Portanto, o medo é a suposição de que alguma situação danosa, em um futuro próximo, possa nos afligir, ou afligir aqueles que nos são caros. Assim como o que acontece com quem odeia, quem teme pode ter medo tanto de pessoas, quanto de coisas, contanto que os males provenientes dessas duas fontes pareçam próximos para quem experiencia tal paixão.

Em qual disposição se encontra quem sente: teme-se porque se espera que algo ruim aconteça, portanto, quem teme se encontra em um estado de espírito em que aguarda a má sorte.

Em relação a quem (ou o que) sente: tudo ou todos que apresente(m) risco a nós ou aos que nos são caros. Sente-se temor pelas ações daqueles que estão acima de nossa jurisdição, ou seja, sentimos medo daqueles, ou daquelas coisas, que fogem do nosso controle, cujo poder nos sobrepuja ou cujo destino 
não nos diz respeito. Assim, teme-se tudo que seja poderoso, inconsequente e imprevisível.

Em qual circunstância sente: aquele que teme, sente-se de tal maneira por sentir-se à mercê de algo ou alguém que tem poder de lhe infligir algum mal.

Quadro 5 - Premissas do medo

\begin{tabular}{|c|c|c|}
\hline \multicolumn{3}{|c|}{ Medo } \\
\hline $\begin{array}{l}\text { Em qual disposição se } \\
\text { encontra quem sente: }\end{array}$ & Contra quem sente: & Em qual circunstância: \\
\hline Expectativa. & $\begin{array}{l}\text { Todo aquele ou tudo aquilo } \\
\text { que tenha poder para nos } \\
\text { causar mal, ou aos que } \\
\text { nos são caros, quando } \\
\text { não podemos remediar tal } \\
\text { poder. }\end{array}$ & $\begin{array}{l}\text { Quando acredita que } \\
\text { sua sorte está à mercê } \\
\text { do poder de outrem que } \\
\text { possa lhe causar mal, } \\
\text { ou causar mal aos seus } \\
\text { queridos. }\end{array}$ \\
\hline
\end{tabular}

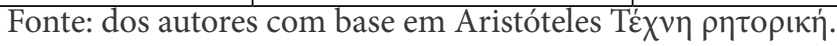

\section{A confiança (segurança)}

Assim como o temor, a confiança (segurança, também descrita como esperança) é acompanhada de expectativa, porém, de que exista uma solução a uma

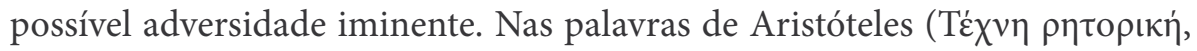
II, 5, 1383a), a confiança "é o contrário do [temor; o que inspira confiança é o contrário do] temível, de sorte que a esperança é acompanhada da suposição de que os meios de salvação estão próximos, enquanto os temíveis ou não existem, ou estão distantes".

Em qual disposição se encontra quem sente: sente-se confiante aquele que acredita ter sido justo, sensato e temerário. Ademais, sente esperança aquele que acredita ser justo e possuir expectativa de que não lhe ocorra algum mal, ou que tal mal possa ser superado.

Em relação a quem (ou o que) sente: sentimo-nos seguros diante daqueles que não nos apresentam riscos, ou porque são poderosos e nos querem bem, ou porque são fracos e não nos apresentam adversidade e, também, porque são nossos amigos e nos apreciam. Além disso, sentimo-nos seguros em relação a um mal que possa ser sobrepujado por nós, pois, nesse caso, possuímos meios de não deixar que tal situação adversa nos traga algum resultado penoso.

Em qual circunstância sente: quando acreditamos estar distante do temível e próximo dos meios de salvação ou pensamos estar sob o poder daqueles que nos querem bem, ou querem bem aos nossos queridos ou, ainda, quando possuímos artifícios para nos livrar de algum mal. 
Uma incursão ao pathos: o método aristotélico de descrição das

Quadro 6 - Premissas da esperança

\begin{tabular}{|l|l|l|}
\hline \multicolumn{2}{|c|}{ Esperança } \\
\hline $\begin{array}{l}\text { Em qual disposição se } \\
\text { encontra quem sente: }\end{array}$ & Contra quem sente: & Em qual circunstância: \\
\hline Expectativa. & $\begin{array}{l}\text { Todo aquele ou tudo aquilo } \\
\text { que tenha poder para nos } \\
\text { livrar de algum mal, ou aos } \\
\text { que nos são caros. }\end{array}$ & $\begin{array}{l}\text { Quando se acredita estar } \\
\text { distante do temível e } \\
\text { próximo dos meios de } \\
\text { salvação. }\end{array}$ \\
\hline
\end{tabular}

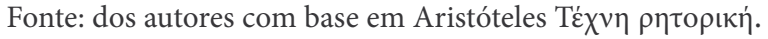

\section{A vergonha}

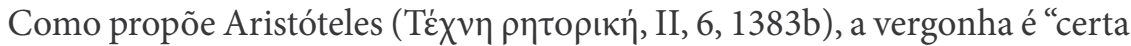
tristeza ou perturbação com respeito aos vícios presentes, passados ou futuros, que parecem levar à desonra". Portanto, é válido compreender a vergonha como a paixão que traz desgosto em relação à descoberta por outrem de fatos dos quais não nos orgulhamos. Assim, sente-se vergonha quando alguém tem ciência de uma característica ou fato de nós que não é bem vista(o) socialmente e que, por consequência, pode nos trazer descrédito. Em adição à definição anterior, o autor adiciona: "a vergonha é uma representação concernente à má

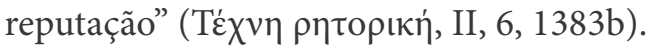

Em qual disposição se encontra quem sente: o envergonhado encontrase de tal maneira por dar crédito à opinião alheia, portanto, quando está em certa disposição de espírito que valoriza o julgamento de outrem, encontra-se passível de ser acometido pela vergonha.

Em relação a quem sente: sente-se envergonhado daqueles que são estimados, ou cuja opinião importa, ou que admiram o envergonhado.

Em qual circunstância sente: quando alguma falta nossa, ou daqueles que nos são caros, parece ser desonrosa. Normalmente vícios de caráter são vergonhosos, pois apresentam um defeito profundo. Portanto, quando qualquer característica que não está de acordo com os padrões sociais aceitáveis nossa é exposta, sentimos vergonha. 
Quadro 7 - Premissas da vergonha

\begin{tabular}{|l|l|l|}
\hline \multicolumn{3}{|c|}{ Vergonha } \\
\hline $\begin{array}{l}\text { Em qual disposição se } \\
\text { encontra quem sente: }\end{array}$ & Contra quem sente: & Em qual circunstância: \\
\hline $\begin{array}{l}\text { Dá valor ao julgamento } \\
\text { (opinião) alheio(a). }\end{array}$ & $\begin{array}{l}\text { Todo aquele cuja opinião } \\
\text { nos importa, ou porque } \\
\text { nos admira ou porque o } \\
\text { admiramos. }\end{array}$ & $\begin{array}{l}\text { Quando alguma falta que } \\
\text { causa desonra é passível } \\
\text { de ser descoberta por } \\
\text { aqueles cujo julgamento } \\
\text { nos é caro. }\end{array}$ \\
\hline
\end{tabular}

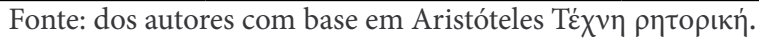

\section{A impudência (desvergonha)}

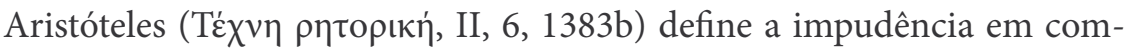
paração com a vergonha e afirma que ela é "certo desdém ou indiferença" em relação aos defeitos do presente, passado ou futuro que poderiam causar desonra. Aristóteles afirma que as três premissas fundamentais da impudência expressam o contrário do que é exposto na vergonha.

Em qual disposição se encontra quem sente: experienciam a impudência aqueles cujo estado de espírito não valoriza a opinião ou julgamento de outem. Portanto, quando a concepção do outro sobre mim não me é cara, sou impudente.

Em relação a quem sente: sentimos impudência por aqueles que não estimamos e, por consequência, não nos importa o que pensam. Assim, somos impudentes contra aqueles cujo estima não nos é cara.

Em qual circunstância sente: o impudente sente tal paixão quando algum defeito de seu caráter, usualmente repreensível socialmente, é exposto, porém, tal fato não desperta sentimento de desgosto proveniente da vergonha. Dessa forma, se não sente vergonha pela exposição de seu defeito, sentirá impudência.

Quadro 8 - Premissas da impudência

\begin{tabular}{|c|c|c|}
\hline \multicolumn{3}{|c|}{ Impudência } \\
\hline $\begin{array}{l}\text { Em qual disposição se } \\
\text { encontra quem sente: }\end{array}$ & Contra quem sente: & Em qual circunstância: \\
\hline $\begin{array}{l}\text { Não dá valor ao } \\
\text { julgamento (opinião) } \\
\text { alheio(a). }\end{array}$ & $\begin{array}{l}\text { Todo aquele cuja opinião não } \\
\text { nos importa, ou porque é } \\
\text { inferior a nós ou porque sua } \\
\text { opinião não nos afeta. }\end{array}$ & $\begin{array}{l}\text { Quando alguma falta que } \\
\text { normalmente causaria } \\
\text { desonra é passível de ser } \\
\text { descoberta, porém por } \\
\text { aqueles cujo julgamento não } \\
\text { nos é caro. }\end{array}$ \\
\hline
\end{tabular}

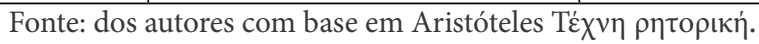


Uma incursão ao pathos: o método aristotélico de descrição das

\section{O favor}

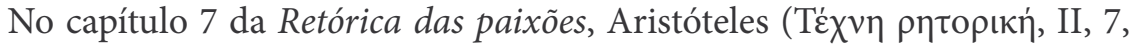
1385a) define o favor como "o serviço pelo qual, diz-se, aquele que possui concede ao que tem necessidade, não em troca de alguma coisa, nem com o fim de obter alguma vantagem pessoal, mas no interesse do favorecido".

Em qual disposição se encontra quem sente: o obsequioso sente-se de tal forma por encontrar-se em estado de espírito que possibilite enxergar a necessidade alheia diante de uma adversidade.

Em relação a quem sente: sente-se favor pelos que possuem uma necessidade, em especial pelos que possuem uma carência da qual a causa não nos afeta, por dispormos de fartura nesse mesmo aspecto. Portanto, sente-se favor por aqueles que não possuem o que podemos oferecer e tal falta lhes causa desgosto.

Em qual circunstância sente: uma vez que o favor é o sentimento de atenção ao outro em necessidade, sente-se favor quando a necessidade alheia apela ao nosso emocional, justamente por dispormos de meios para sanar tal necessidade.

Quadro 9 - Premissas do favor

\begin{tabular}{|l|l|l|}
\hline \multicolumn{3}{|c|}{ Favor } \\
\hline $\begin{array}{l}\text { Em qual disposição se } \\
\text { encontra quem sente: }\end{array}$ & Contra quem sente: & Em qual circunstância: \\
\hline $\begin{array}{l}\text { De compreensão em } \\
\text { relação à necessidade } \\
\text { alheia. }\end{array}$ & $\begin{array}{l}\text { Todo aquele que é acometido por } \\
\text { desgosto proveniente de carência, } \\
\text { falta e necessidade cujos meios } \\
\text { de solução desfrutamos em } \\
\text { abundância. }\end{array}$ & $\begin{array}{l}\text { Quando a necessidade } \\
\text { alheia apela ao nosso } \\
\text { emocional por dispormos } \\
\text { de meios para saná-la. }\end{array}$ \\
\hline
\end{tabular}

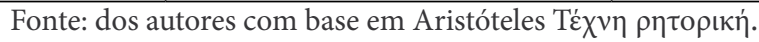

\section{A compaixão}

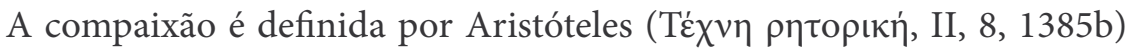
como "pesar por um mal que se mostra destrutivo ou penoso, e atinge quem não o merece, mal que poderia esperar sofrer a própria pessoa ou um de seus parentes, e isso quando esse mal parece iminente". Portanto, a compaixão é uma dor sentida por aqueles que veem outrem sofrer injustamente, quando tal mal poderia também acometê-los.

Em qual disposição se encontra quem sente: sente compaixão aquele que está em um estado de espírito que lhe permita sentir empatia pela posição do outro. Dessa forma, por poder imaginar-se na posição do sofredor é que o sujeito sente compaixão. 
Em relação a quem sente: sentimos compaixão por aquele que sofre algum mal que julgamos imerecido, e, ademais, por tal mal ser passível de ocorrência em nossas vidas. Porém, a pessoa acometida pelo mal não deve ser próxima em laço, como um filho, porque nesse caso, ao invés da compaixão, a emoção despertada seria o terror, e o terror desperta medo. $\mathrm{O}$ sofredor tão pouco deve ser indigno, indecente, pois só se sente compaixão por aqueles que sofrem imerecidamente de algum mal.

Em qual circunstância sente: quando se compreende que outros sofrem males pelos quais foram injustamente sentenciados. Quando tal mal ocorre na vida daqueles que possuem traços em comum conosco e, justamente por serem equivalentes a nós, compreendemos que tal mal é sofrido imerecidamente.

Quadro 10 - Premissas da compaixão

\begin{tabular}{|c|c|c|}
\hline \multicolumn{3}{|l|}{ Compaixão } \\
\hline $\begin{array}{l}\text { Em qual disposição se } \\
\text { encontra quem sente: }\end{array}$ & Contra quem sente: & Em qual circunstância: \\
\hline $\begin{array}{l}\text { De empatia pelo infortúnio } \\
\text { sofrido por outrem } \\
\text { imerecidamente. }\end{array}$ & $\begin{array}{l}\text { Todo aquele que é } \\
\text { acometido por desgosto } \\
\text { imerecido e que possui } \\
\text { algum traço em comum } \\
\text { conosco (como idade, } \\
\text { posição social, profissão). }\end{array}$ & $\begin{array}{l}\text { Quando se compreende um } \\
\text { infortúnio sofrido por outro } \\
\text { como injusto e também } \\
\text { quando tal infortúnio poderia } \\
\text { nos afetar injustamente. }\end{array}$ \\
\hline
\end{tabular}

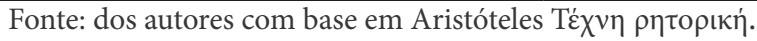

\section{A indignação}

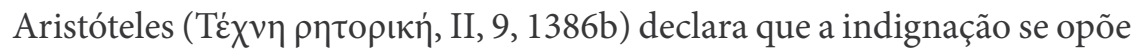
à compaixão. O mestre define tal paixão como "o pesar pelos sucessos imerecidos". Portanto, ela pode ser compreendida como um sentimento de dor em relação a alguma aclamação, algum sucesso ou alguma fortuna que decorrem contrariamente ao mérito. Dessa forma, indignamo-nos contra aqueles que são felizes sem merecimento, uma vez que "a indignação é sentimento de pesar por quem parece ser feliz imerecidamente".

Em qual disposição se encontra quem sente: o indignado se encontra de tal forma pela suposição de que uma injustiça foi cometida por alguém, ou pelo destino, e tal injustiça conferiu bens que são imerecidos por seu detentor.

Em relação a quem sente: sente-se indignação por todos aqueles que não merecem os bens que detêm.

Em qual circunstância sente: quando alguém goza de bens ou sucesso que não deveriam lhe pertencer de acordo com o julgamento daquele que sente indignação. 
Uma incursão ao pathos: o método aristotélico de descrição das

Quadro 11 - Premissas da indignação

\begin{tabular}{|c|c|c|}
\hline \multicolumn{3}{|l|}{ Indignação } \\
\hline $\begin{array}{l}\text { Em qual disposição se } \\
\text { encontra quem sente: }\end{array}$ & Contra quem sente: & Em qual circunstância: \\
\hline $\begin{array}{l}\text { De suposição de injustiça } \\
\text { proveniente de sucesso/ } \\
\text { felicidade obtido/a por } \\
\text { outrem imerecidamente. }\end{array}$ & $\begin{array}{l}\text { Todo aquele que goza } \\
\text { de felicidade imerecida. }\end{array}$ & $\begin{array}{l}\text { Quando se compreende que } \\
\text { o sucesso ou a felicidade } \\
\text { experienciada por outrem é } \\
\text { obtido(a) sem mérito. }\end{array}$ \\
\hline
\end{tabular}

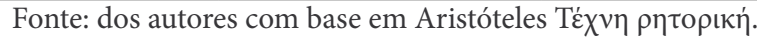

\section{A inveja}

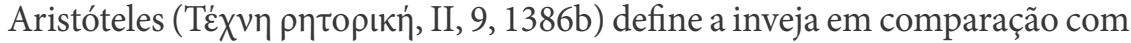
a indignação da seguinte maneira: "a inveja é também um pesar perturbador ante um sucesso, entretanto não de pessoa indigna, mas igual e semelhante a nós".

O autor continua sua descrição dessa paixão ao afirmar que: "inveja é certo pesar pelo sucesso evidente (...) em relação aos nossos iguais, não visando ao

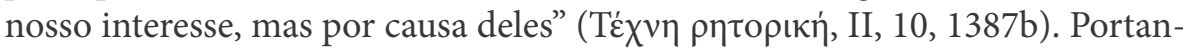
to, é plausível compreender a inveja como sentimento de dor proveniente de bem possuído por outrem, quando não obtemos também tal bem e, na mesma medida, objetivamos desprover seu detentor de sua posse.

Em qual disposição se encontra quem sente: inferiorizado e diminuído em relação a outrem que considera seu semelhante.

Em relação a quem sente: sente-se inveja quando se acredita que o detentor de um bem que nos é caro, e não possuímos, é semelhante a nós em alguma espécie.

Em qual circunstância sente: quando deseja que o bem possuído por aquele que se julga semelhante a nós não o possua.

Quadro 12 - Premissas da inveja

\begin{tabular}{|l|l|l|}
\hline \multicolumn{2}{|c|}{ Inveja } \\
\hline $\begin{array}{l}\text { Em qual disposição se } \\
\text { encontra quem sente: }\end{array}$ & Contra quem sente: & Em qual circunstância: \\
\hline $\begin{array}{l}\text { Inferiorizado diante daquele } \\
\text { que julga seu semelhante. }\end{array}$ & $\begin{array}{l}\text { Todo aquele que } \\
\text { consideramos semelhante } \\
\text { a nós e que detém um } \\
\text { bem que nos é caro e não } \\
\text { possuímos. }\end{array}$ & $\begin{array}{l}\text { Quando se deseja que o } \\
\text { bem detido por outrem, } \\
\text { semiquilado a nós, seja }\end{array}$ \\
\hline
\end{tabular}

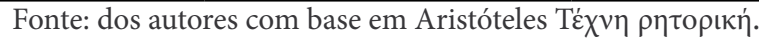




\section{A emulação}

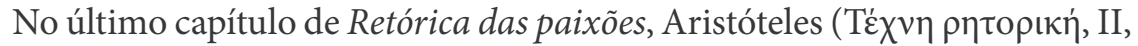
10, 1388a) define a emulação como "pesar pela presença manifesta de bens valiosos que nos é possível adquirir, sentido com respeito aos que são por natureza nossos semelhantes, não porque esses bens pertencem a um outro, mas porque não nos pertencem também". A emulação também é chamada por Aristóteles como competição. Diferentemente da inveja, que é pesar pelo bem detido por outrem, não porque não o possuímos, mas porque outrem possui, a emulação é evocada quando desejamos para nós um bem que outro possui, sem que o outro deixe de possuí-lo. Dessa forma, enquanto a inveja cria a vontade de destruir o bem de outrem, e não necessariamente o adquirir, a emulação nos impulsiona a adquirir o mesmo bem possuído por outrem, com vistas a igualá-lo. Além disso, o estagirita descreve a paixão da emulação como "um sentimento digno e próprio de pessoas dignas, enquanto a inveja é vil e peculiar aos espíritos vis"

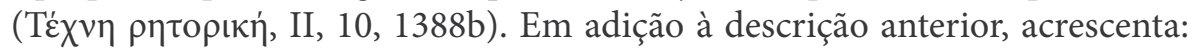
"um se dispõe, pela emulação, a obter os bens, o outro, pela inveja, a impedir

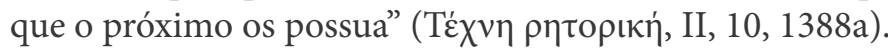

Em qual disposição se encontra quem sente: inferiorizado e diminuído em relação a outrem que considera seu semelhante, porém apto a se superar.

Em relação a quem sente: sente-se emulação quando se acredita que o detentor de um bem que nos é caro, e não possuímos, é semelhante a nós em alguma espécie.

Em qual circunstância sente: quando deseja que o bem possuído por aquele que se julga semelhante a nós também seja nosso.

Quadro 13 - Premissas da emulação

\begin{tabular}{|l|l|l|}
\hline Emulação & Em qual circunstância: \\
\hline $\begin{array}{l}\text { Em qual disposição se } \\
\text { encontra quem sente: }\end{array}$ & Contra quem sente: & $\begin{array}{l}\text { Quando se deseja que o } \\
\text { bem detido por outrem, } \\
\text { semelhante a nós, } \\
\text { também seja nosso. }\end{array}$ \\
\hline $\begin{array}{l}\text { Inferiorizado diante daquele } \\
\text { que julga seu semelhante, } \\
\text { porém apto a se superar. }\end{array}$ & $\begin{array}{l}\text { Todo aquele que consideramos } \\
\text { nosso semelhante e que detém } \\
\text { um bem que nos é caro e não } \\
\text { possuímos. }\end{array}$
\end{tabular}

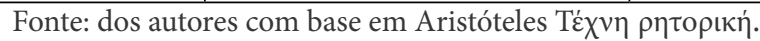

\section{O desprezo}

Aristóteles define sua última paixão da Retórica, o desprezo, como "o contrário da emulação". 
Uma incursão ao pathos: o método aristotélico de descrição das paixões e a relação hierárquica delas emanada

Em qual disposição se encontra quem sente: sente desprezo quem acredita não ter o que invejar/emular, portanto, quem experimenta a falta de ambição, em determinada instância, por já ter obtido tudo o que desejava.

Em relação a quem sente: sente-se tal paixão em relação àqueles considerados indignos de nossa emulação ou inveja, por não possuírem nada que seja caro aos nossos olhos.

Em qual circunstância sente: quando se acredita estar em tal posição que propicie a plenitude e felicidade, ao passo que nada mais é possível desejar para se alcançar a completude.

Quadro 14 - Premissas do desprezo

\begin{tabular}{|l|l|l|}
\hline \multicolumn{2}{|c|}{ Desprezo } & Em qual circunstância: \\
\hline $\begin{array}{l}\text { Em qual disposição se } \\
\text { encontra quem sente: }\end{array}$ & Contra quem sente: & Quando se acredita \\
\hline $\begin{array}{l}\text { Sem ambição por sua } \\
\text { superioridade, pelo fato de } \\
\text { possuir tudo que é possível } \\
\text { desejar em determinado } \\
\text { campo da vida. }\end{array}$ & $\begin{array}{l}\text { Todo aquele que não detém o } \\
\text { que consideramos ideal ou que } \\
\text { possuímos de bom. }\end{array}$ & $\begin{array}{l}\text { determinada instância } \\
\text { da existência humana. }\end{array}$ \\
\hline
\end{tabular}

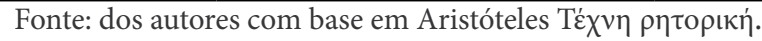

Uma vez estabelecidas as premissas utilizadas por Aristóteles para cada uma das paixões, passemos às relações hierárquicas delas decorrentes.

\section{Relações hierárquicas emanadas das paixões}

Uma vez que descrevem as representações pessoais que os indivíduos envolvidos em um contexto persuasivo constroem uns dos outros, as paixões destacam o caráter interpessoal das relações humanas. Não por acaso, Meyer, no prefácio de Retórica das paixões, define as paixões aristotélicas da seguinte forma: "Nem meios nem fins, as paixões são as respostas às representações que os outros concebem de nós, são representações em segundo grau. Mais tarde, serão chamadas formas de consciência de si”. ${ }^{2}$

As paixões descritas por Aristóteles na Retórica são compreendidas como uma resposta do outro em relação àquele que é o evocador de uma dada paixão. Por isso, Meyer enfatiza que as "paixões refletem (...) as representações que 
fazemos dos outros, considerando-se o que eles são para nós, realmente ou no domínio da imaginação". ${ }^{3}$

A proposição contida nesta seção do texto se fundamenta na seguinte afirmação de Meyer: "A retórica é antes de tudo um ajuste de distância entre os indivíduos. (...) A lógica de toda retórica é (...) a identidade e a diferença; [da distância e da proximidade]". ${ }^{4}$ Dessa forma, a relação entre aquele que sente determinada paixão e aquele que a desperta é sempre de igualdade ou diferença, podendo ser esta de superioridade ou inferioridade.

Nesta seção, descreveremos como as paixões podem ser observadas sob essa ótica, da relação hierárquica entre os sujeitos, para propor uma nova categoria de descrição das paixões aristotélicas, isto é, uma nova premissa.

\section{A Cólera (ira)}

A cólera diz respeito a um sentimento que desestabiliza uma relação entre dois sujeitos. Aquele que se encontra colérico está instável na relação de forma a sentir-se desprezado, ultrajado ou difamado, ou seja, inferiorizado, desmerecidamente, em relação àquele que desperta seu estado de cólera. Por sua vez, aquele que desperta a cólera sente-se superior ao encolerizado, uma vez que do contrário, se estivesse em pé de igualdade com o outro, buscaria a harmonia, a paridade. Como vimos, aqueles que desprezam, ultrajam ou difamam, o fazem porque sabem que o outro não pode atingi-los, portanto, o fazem porque se consideram superiores. Por fim, aquele que sente cólera, se sente de tal forma por acreditar estar sofrendo imerecidamente algum mal, sendo subjugado e menosprezado pelo desdém de outrem à sua situação.

\section{A Calma}

A calma, de acordo com a reflexão aristotélica, é a ausência da cólera. Dessa forma, ela se apresenta na falta do desprezo, do desdém e da difamação. Se o colérico sente-se de tal forma em função do desprezo que julga sofrer, aquele que sente calma sente-se assim por acreditar que quando agem contra ele, não agem ou com má intenção ou imerecidamente. Além disso, o estagirita afirma 
Uma incursão ao pathos: o método aristotélico de descrição das paixões e a relação hierárquica delas emanada

que sentimos calma sob o poder daqueles que tememos ou respeitamos, ao lado daqueles que são nossos pares e acima daqueles que se arrependem pelo que fizeram contra nós e, por tamanha injustiça, humilham-se diante de nós em função de nosso perdão. Logo, fica evidente que a relação hierárquica em relação àquele que sente calma, com aquele que evoca a calma, está presente no despertar dessa paixão. Tal afirmação, acreditamos, encontra fundamentos ao passo que, para temermos ou respeitarmos alguém, tal pessoa deve ser considerada superior em relação a nós, em algum aspecto. Se tememos, é porque não temos controle do que o outro pode nos fazer, não temos capacidade de nos defender, caso algo venha a acontecer. Na mesma medida, se respeitamos, consideramos a pessoa digna de respeito por tê-la bem quista em nossa interpretação, ou seja, nós a respeitamos porque ela merece tal respeito. Assim, de uma forma ou de outra, aquele que nos evoca a calma (por deter poder sobre nós e nos proteger com tal poder, ou ao menos não nos causar nenhum mal) está diretamente superior a nós em algum aspecto que nos influencie sentir temor ou respeito. $\mathrm{O}$ temor ao qual Aristóteles faz referência não nos parece ser o temor do medo, uma de suas paixões descritas, mas sim o temor que impele o sentimento de profundo respeito e obediência. Além disso, sentimo-nos calmos quando quem nos fez um mal, não o fez intencionalmente (e sabemos que não foi intencional por possuirmos relação par com a pessoa, de proximidade; ademais, quando conhecemos e dividimos traços em comum, acreditamos poder confiar na natureza de outrem). Nesse aspecto, quando sentimos calma em relação a alguém cujos atos acreditamos não possuir maldade, por serem semelhantes aos nossos atos, encontramo-nos em uma relação hierárquica de igualdade, ou seja, de paridade com quem desperta a calma em nós. Por fim, sentimos calma também quando quem nos fez algum mal, reconhece sua falta e se humilha em função do perdão e, dessa forma, diminui-se perante a nós.

Qualquer que seja a situação, a calma revela que o outro não pode, ou não deseja, nos atingir. Portanto, diferentemente da cólera - em que o inferiorizado se encoleriza e o superiorizado desdenha, difama ou despreza -, na calma, tanto aquele que está acima na relação, quanto o que está abaixo, bem como aquele que se encontra em posição equiparada, pode se sentir calmo.

\section{O amor (amizade)}

Para Aristóteles, a relação daquele que ama com aquele que é amado é representada pela reciprocidade. Dessa maneira, o que ama enxerga aquele que ama como igual, equivalente. Portanto, quem ama não inferioriza, muito menos superioriza o outro. A relação criada por essa paixão, então, é de harmoniosa 
simetria. Amar, no pensamento aristotélico, é querer o bem ao outro, não por nós, mas em função do outro. Na infinidade de circunstâncias em que somos capazes de amar, a descrição aristotélica dessa paixão destaca sempre a relação de paridade de quem ama para com quem é amado. Nessa relação de igualdade, as formas de amar são o companheirismo, a familiaridade, o parentesco, bem como todas as relações dessa mesma espécie. Em consonância, o que causa o amor, então, são todas as ações passíveis de serem caracterizadas como despretensiosas, desinteressadas e espontâneas.

\section{O ódio (inimizade)}

De acordo com o pensador, o que causa o ódio, em contraposição com o que causa a cólera, são as coisas que podem ser menos perceptíveis, como a injustiça e a insensatez. Aristóteles ainda afirma que aquele que sente ódio (ou inimizade) não é capaz de sentir compaixão e, além disso, deseja que o causador de seu ódio desapareça. Ao analisar atentamente a descrição do estagirita a respeito do ódio, é possível compreender seu caráter arrebatador. Aquele que é tomado por essa paixão encontra-se fora de si, atordoado, cego por um sentimento avassalador, capaz de anular a razão como nenhuma outra emoção pode fazer, daí talvez provenha a expressão "cego de ódio". Quem odeia não tem espaço para a compaixão, ou mesmo para refletir sobre a posição do outro. É como se o ódio tomasse a alma daquele que o sente por completo, impossibilitando que outro estado mental/psicológico entre em jogo.

Por meio do exposto, fica claro que a relação hierárquica de quem sofre tal emoção em relação com quem a causa é de inferioridade. Quem sente ódio, apesar de não possuir um sujeito específico para odiar, odeia uma classe, um grupo, um tipo e, portanto, sente-se inferiorizado por tal classe, grupo ou tipo.

\section{O temor (medo)}

O medo, ou temor, como descreve o filósofo, é um desgosto que aflige aqueles que acham que algum mal está à espreita, prestes a irromper em suas vidas. $\mathrm{O}$ medo é sentido em razão de um mal que pode assolar a nossa ou a existência daqueles que amamos. Dessa forma, a expectativa está intrinsecamente ligada ao medo já que, ao temermos, esperamos que alguma ação indesejada nos afete de uma maneira que não desejamos. São temidas as coisas que fogem do nosso controle, por não termos poder suficiente para controlá-las ou impedi-las, como uma doença sem cura ou alguém com poder avassalador que possa nos ameaçar. 
Uma incursão ao pathos: o método aristotélico de descrição das paixões e a relação hierárquica delas emanada

No que diz respeito à relação de assimetria ou simetria, entre quem sente o temor e quem o causa, fica evidente, com a descrição anterior, que aquele que sente medo superioriza, em relação a si próprio, o causador de seu medo. Como vimos, tememos o que extrapola o nosso controle, portanto é temível tudo aquilo que tem capacidade de nos afetar negativamente. Dessa forma, para que eu sinta medo, preciso admitir que o que me dá medo tem meios mais eficientes que os meus para causar tal mal, assim, está acima de mim em certo contexto, a ponto de impossibilitar a prevenção do suposto mal que está por vir.

\section{A confiança}

Aristóteles delineia a confiança como o contrário do temor. Enquanto o temor está atrelado à expectativa de um mal, a esperança está atrelada à expectativa de um bem, de uma ação positiva que acontecerá na vida daquele que é tomado por tal emoção. Dessa forma, ambas as paixões se referem a uma projeção do futuro, a uma ânsia pelo desenrolar de um acontecimento. O pensador nos faz refletir, também, acerca de que a esperança é sentida quando o que causa medo está distante ou não existe. Como acontece com outras paixões, podemos sentir a confiança tanto em relação a uma pessoa, como em relação a uma situação/coisa.

Com base na relação de simetria ou assimetria entre os sujeitos envolvidos no despertar da esperança (confiança), fica claro que aquele que sente tal paixão sente-se: inferior quando depende de outrem para o proteger de um mal; ou superior quando acredita deter os meios e recursos para evitar um possível mal futuro.

\section{A vergonha}

No que concerne à vergonha, podemos pensá-la como um mal-estar que provém de faltas nossas descobertas por outrem, ou seja, a vergonha, como definida por Aristóteles, é compreendida como um incômodo que nos aflige quando algo de nossa parte que não é honroso torna-se de conhecimento alheio, em especial daqueles cuja opinião nos é cara. Dessa forma, é evidente a extrema relação de assimetria emanada dessa paixão. Quando sinto vergonha, considero o outro, que sabe da minha falta, mais nobre, superior, pois a minha falta, o meu vício, me torna inferior. Além disso, o outro está superiormente hierarquizado porque sua opinião, sobre o que fiz, me importa. Dessa forma, me envergonho porque dou crédito ao que pensa o outro. 


\section{A impudência (desvergonha)}

A impudência é exaltada na falta de crédito que atribuo à opinião alheia. Quando sinto impudência, não me importa o que o outro acha ou pensa de mim. Dessa forma, a relação que a impudência cria entre os sujeitos é de assimetria e coloca o que sente tal emoção, pelo menos em sua concepção, acima daquele em relação ao qual se sente impudente. Portanto, a impudência é um vínculo dissociador em que a opinião do outro se faz irrelevante.

\section{O favor}

A paixão do favor relaciona-se ao altruísmo e, por isso, claramente pode ser considerada a mais rara das paixões. Presta-se um favor quando não se tem nenhuma intenção de obter benefício para si. Tal concepção é, de certa maneira, utópica na realidade prática, uma vez que é considerada por muitos como inexistente de forma genuína na alma humana. A relação criada entre os sujeitos, pelo favor, é de assimetria. Só presta um favor aquele que está em posição avantajada em relação a quem necessita de favor. Dessa forma, o que sente favor por outrem sabe que não está na mesma situação de quem sofre do mal que suscita tal paixão, uma vez que do contrário, não estaria em condições de ser solicito.

\section{A compaixão}

Suscita a compaixão o mal que atinge aqueles que julgamos não ter merecido tal mal. Em especial, sentimos compaixão quando acreditamos que tal mal possa afligir injustamente a nós ou àqueles que amamos. Dessa forma, quem sente compaixão enxerga a dor do outro e, ao mesmo tempo, admite que poderia estar na mesma situação que ele. Portanto, a compaixão demonstra uma relação de simetria entre aquele que sente e aquele que causa tal paixão, uma vez que sentimos de tal forma quando podemos enxergar a dor do outro como nossa, e isso só é possível porque compartilhamos uma posição próxima, parecida, com aquele que é acometido por tal dor. Quando sentimos compaixão e nos julgamos capazes de ajudar o outro a se livrar do mal que o acomete, podemos ser conduzidos a experienciar a paixão do favor, justamente por determos os meios necessários para auxiliar aquele que sofre a pena imerecida. ${ }^{5}$

5 No contexto religioso, a palavra "misericórdia" apresenta uma acepção bem mais ampla do que aquela descrita por Aristóteles como "compaixão". A misericórdia, nesse contexto, envolve minimamente três paixões: o amor, a compaixão e o favor. (SOUZA; FIGUEIREDO, 2010) 
Uma incursão ao pathos: o método aristotélico de descrição das

\section{A indignação}

Sente-se indignação por aqueles que são infelizes ou felizes imerecidamente. Em razão do ponto de vista, pode-se compreender que aquele que causa indignação pode estar tanto em posição superior, quanto inferior, porém, a relação sempre será de assimetria. Aquele que sente a indignação, por sua vez, pode se encontrar inferiorizado, em relação a quem desperta tal emoção, se o causador é feliz sem merecimento, como os políticos que enriquecem em razão do roubo à população. No entanto, aquele que se sente indignado frente a alguém que é infeliz injustamente estará em posição superior, uma vez que, se se colocasse na mesma posição do infeliz, sentiria compaixão.

\section{A inveja}

Se sentimos, como na indignação, aflição pelo bem de outrem que julgamos imerecido, porém, que não possuíamos, mas poderíamos possuir e, além disso, consideramo-nos semelhante, igual, àquele que desperta tal paixão em nós, sentimos inveja. A inveja é despertada quando um sujeito não aceita que outro possua aquilo que também poderia ter, mas não tem. Ela desvela uma relação assimétrica, em que quem sente superioriza quem a desperta. Justamente, ela é o brado pela recuperação de uma relação simétrica, uma vez que o sujeito tomado pela inveja deseja destruir o que o outro possui para reestabelecer a relação de simetria. É necessário apontar que o que realmente desencadeia a inveja não é o fato de o invejoso não possuir tal bem, mas sim de o outro o possuir.

Como ressalta Figueiredo:

Identidade almejada e diferença camuflada. Assim parece se constituir a realidade com que se depara o invejoso. Por essa razão, penso que sentimos inveja quando, cientes da nossa incapacidade de trilhar as rotas necessárias para atingir as metas desejadas, temos o desejo oculto de encontrar um atalho. Obviamente, esse atalho jamais nos conduzirá aos lugares que almejamos, e é exatamente esse aspecto que distanciará a inveja da emulação. ${ }^{6}$

6 Figueiredo, 2017, p. 217 


\section{A emulação}

A emulação, também vista por Aristóteles como competição, é o sentimento daquele que reconhece um bem que almeja em posse de outrem. Assim como na inveja, o êmulo sente tal paixão por não possuir um bem que não é seu, porém, diferente do invejoso, o êmulo não fita destruir o bem alheio, mas sim obtê-lo bem da mesma forma que seu adversário. Por estabelecer essa relação antagônica entre quem sente e quem causa, a relação emanada da emulação é de assimetria, como na inveja. Quem é êmulo admite que está inferior em relação ao alvo da emulação, porém, por ser um semelhante, acredita que possa igualá-lo.

\section{O desprezo}

Na visão aristotélica, o desprezo é o contrário da emulação. Ademais, consequentemente, emular é o contrário de desprezar. Dessa forma, se emulo, coloco o outro em uma posição superior à minha, dou importância à situação do outro, validando-o. Ao desprezar, ao contrário, coloco-me superior ao outro, uma vez que ele pouco importa a mim, bem como suas conquistas e bens; assim, ele é invalidado. O desprezo, então, é a indiferença e estabelece uma relação assimétrica de ruptura com o outro, assim como o ódio, porém, quem é alvo do desprezo é invalidado por quem o sente.

\section{Simetrias e assimetrias oriundas das paixões}

Em consonância com a descrição da relação hierárquica emanada do despertar das paixões, o seguinte quadro foi redigido, para efeito comparativo, com o intuito de sinalizar as características específicas de cada paixão.Quadro 15 - Relações hierárquicas emanadas das paixões 
Uma incursão ao pathos: o método aristotélico de descrição das paixões e a relação hierárquica delas emanada

\begin{tabular}{|l|l|l|}
\hline Paixão & Relação hierárquica & Posição de quem sente \\
\hline Cólera & assimétrica & inferior \\
\hline Calma & assimétrica/simétrica & inferior, superior ou igual ${ }^{1}$ \\
\hline Amor & simétrica & igual \\
\hline Ódio & assimétrica & inferior \\
\hline Temor & assimétrica & inferior \\
\hline Confiança & assimétrica & inferior ou superior \\
\hline Vergonha & assimétrica & inferior \\
\hline Impudência & assimétrica & superior \\
\hline Favor & assimétrica & superior \\
\hline Compaixão & simétrica & igual \\
\hline Indignação & assimétrica & inferior ou superior \\
\hline Inveja & assimétrica & inferior \\
\hline Emulação & assimétrica & inferior \\
\hline Desprezo & assimétrica & superior \\
\hline
\end{tabular}

Fonte: elaboração dos autores.

\section{Considerações finais}

Como foi explanado nas diversas seções deste capítulo, as paixões aristotélicas podem ser consideradas ferramentas profícuas na lide retórica. Elas se apresentam como os meios emocionais pelos quais um orador pode apelar para encaminhar seu auditório à persuasão. É necessário pontuar, no entanto, que, apesar do caráter transitório das paixões (já que estas podem mudar de acordo com a conjuntura ou desejo do orador), as premissas que as despertam são permanentes, ou seja, a cólera sempre será despertada em função das três premissas descritas que possibilitam sua evocação. Ao mudar uma dessas premissas, muda-se também a paixão que se encontra em jogo.

Em contraponto, há, na descrição aristotélica, um possível desdobramento em relação a determinadas paixões, como no caso da compaixão que pode se desdobrar em favor. Tal fenômeno aponta para uma conexão entre certas paixões, que apresentam importância ímpar para o orador que almeja fazer uso da retórica das paixões para encaminhar seu auditório a processos persuasivos.

Por meio da organização das premissas de cada paixão, com base no método aristotélico, acreditamos ter deixado a constituição interna das paixões mais bem delineada para o leitor. Buscamos esclarecer em qual estado de espírito alguém sente determinada paixão, contra (ou em relação a) quem sente tal paixão e em qual circunstância tal paixão é evocada. 
Além disso, por meio da reflexão presente na última seção deste capítulo, fica patente a relação hierárquica estabelecida por aquele que sente uma paixão em relação àquele ou àquilo que a desperta em si. Tal modo de descrição é profícuo para a Retórica, uma vez que é por meio dele que se pode observar a forma com que as relações interpessoais em âmbito persuasivo funcionam. Em decorrência disso, é proveitoso para o orador observar tais questões, uma vez que influenciar a visão do auditório em relação a outrem é um meio pertinente de se atingir a persuasão.

Por fim, gostaríamos de salientar que os postulados Aristotélicos, refletidos por Meyer, são de grande importância para a compreensão do sistema social no qual estamos inseridos, uma vez que a Retórica está presente, hoje em dia, em diversas instâncias de nossa vida prática, em suas inúmeras manifestações.

\section{Referências}

ARISTÓTELES. Retórica. 2. ed. Tradução de Manuel Alexandre Júnior, Paulo Farmhouse Alberto e Abel do Nascimento Pena. Lisboa: Imprensa Nacional-Casa da Moeda, 2005. (Biblioteca de autores clássicos).

. Retórica das paixões. Prefácio de Michel Meyer. Introdução, notas e tradução do grego de Isis Borges B. da Fonseca. São Paulo: Martins Fontes, 2000. (Coleção Clássicos). FIGUEIREDO, M. F. Desejo e desdém: as paixões da inveja, da emulação e do desprezo. In: FIGUEIREDO, M. F.; RAMÍREZ VIDAL, G.; FERREIRA, L. A. Paixões aristotélicas. Franca: Unifran, 2017. (Foco: Linguística do texto e do discurso, 2). p. 208-225.

MEYER, M. Aristóteles ou a retórica das paixões. (Prefácio). In: ARISTÓTELES. Retórica das paixões. Tradução de Isis Borges B. da Fonseca. São Paulo: Martins Fontes, 2000. p. XVII-LI.

SOUZA, L. A. de; FIGUEIREDO, M. F. Compaixão-misericórdia: uma paixão aristotélica. Diálogos Pertinentes - Revista Científica de Letras, Franca (SP), v. 6, n. 1, p. 143-162, jan./jun. 2010. 